\title{
PEMBATALAN AKTA HIBAH DI PENGADILAN NEGERI PEMATANGSIANTAR: KAJIAN PUTUSAN NOMOR 33/PDT.G/2019/PN.PMS
}

\author{
Alyatama Budify ${ }^{1}$, Jelitamon Ayu Lestari Manurung ${ }^{1}$, \\ Satria Braja Harianja ${ }^{2}$ \\ ${ }^{1}$ Mahasiswa Fakultas Hukum, Universitas Prima Indonesia, Medan \\ ${ }^{2}$ Dosen Fakultas Hukum, Universitas Prima Indonesia, Medan \\ *Penulis Korespondensi: Jelitamon Ayu Lestari Manurung \\ Email Korespondensi: Jelitam2@gmail.com
}

\begin{abstract}
Abstrak Penelitian ini bertujuan untuk mengetahui hak dan kewajiban pemberi hibah yang melakukan pembatalan hibah; akibat hukum terhadap penerima hibah yang kepadanya terjadi pembatalan hibah; serta untuk menganalisis kesesuaian Putusan PN Pematangsiantar No. 33/Pdt.G/2019/PN.Pms dengan ketentuan Perundang-undangan yang berlaku. Jenis penelitian yang digunakan penelitian ini adalah penelitian hukum normatif, dan bersifat deskriptif. Teknik pengumpulan data yang digunakan adalah studi kepustakaan (library research) dan studi dokumen. Adapun teknik analisis data yang digunakan adalah teknik analisis data kualitatif. Hasil penelitian menunjukkan bahwa Pemberi hibah memiliki beberapa hak sebagaimana berdasarkan Pasal 1669, Pasal 1671, dan Pasal 1672 KUHPerdata. Pemberi hibah juga dapat menarik kembali pemberiannya, jika penerima hibah tidak memenuhi kewajiban yang ditentukan dalam akta hibah atau hal-hal lain, sebagaimana berdasarkan Pasal 1688 KUHPerdata. Selanjutnya, akibat hukum terhadap penerima hibah yang kepadanya terjadi pembatalan hibah ialah pengembalian objek hibah dalam keadaan semula sebelum dibuat perjanjian, sebagaimana berdasarkan Pasal 1691 KUHPerdata, dan disertai putusan yang berketetapan hukum tetap. Adapun mengenai Putusan PN Pematangsiantar No. 33/Pdt.G/2019/ PN.Pms, dapat disimpulkan bahwa keputusan tersebut telah sesuai dengan peraturan perundang-undangan yang berlaku.
\end{abstract}

Kata Kunci:

Akibat Hukum;

Hibah;

Pembatalan.

artikel dengan akses terbuka dibawah lisensi CC BY -4.0

\section{PENDAHULUAN}

Negara Indonesia adalah negara hukum yang memberi perlindungan pada kepentingan masyarakat, serta mengatur hubungan antara kelompok maupun individu dengan pemerintah. Pada kaitan tersebut, hukum dibentuk sebagai norma yang akan memperjelas perbuataan apa saja yang dapat, maupun tidak dapat diperbuat oleh 
manusia, demi terciptanya ketertiban dalam kehidupan masyarakat. ${ }^{1}$ Ketertiban masyarakat dapat tercapai dengan adanya suatu norma hukum yang mengharuskan setiap orang berperilaku sesuai norma tersebut, dimana apabila norma tersebut dilanggar, maka orang yang melanggar akan menerima sanksi sebagai konsekuensi hukum bagi tindakannya. ${ }^{2}$

Seiring dengan perkembangan kehidupan masyarakat, persoalan pembagian tanah semakin bersifat kompleks pula, dimana seringkali diikuti dengan berbagai persoalan lain di tengah-tengah masyarakat. Tanah merupakan objek yang selalu saja menjadi rebutan ditengah-tengah masyarakat dari dulu sampai sekarang, karena sifatnya yang tidak hanya memiliki aspek ekonomi semata, namun juga aspek politik, hukum dan sosial. ${ }^{3}$ Salah satu persoalan yang muncul di tengah-tengah masyarakat adalah persoalan hibah. ${ }^{4}$

Hibah adalah suatu pemberian seorang kepada orang lain yang dilakukan pada waktu pemberi dan penerima masih hidup atau belum meninggal. ${ }^{5}$ Hibah mempunyai fungsi sosial dalam kehidupan masyarakat, ${ }^{6}$ dimana sesuatu yang dihibahkan tersebut dapat diberikan kepada siapa saja, tanpa memandang ras, suku, agama, dan golongan, sehingga hibah dianggap sebagai solusi dalam pembagian harta kekayaan. ${ }^{7}$ Meskipun demikian, pada kenyataannya hibah seringkali bukan merupakan solusi yang tepat dalam hal pewarisan tanah, karena bisa jadi menimbulkan masalah baru, misalnya penarikan kembali hibah atau pembatalan hibah. ${ }^{8}$

Lebih lanjut, Pasal 1666 Peraturan Kolonial, Staatsblad Nomor 23 Tahun 1847 tentang Burgerlijk Wetboek voor Indonesie (BW)/Kitab Undang-Undang Hukum Perdata (selanjutnya disebut KUHPerdata), mengatur bahwa:

"Penghibahan adalah suatu persetujuan dengan mana seorang penghibah menyerahkan suatu barang secara cuma-cuma, tanpa dapat menariknya kembali, untuk kepentingan seseorang yang menerima penyerahan barang itu. Undang-undang hanya mengakui penghibahan-penghibahan antara orangorang yang masih hidup."

Sehubungan dengan ketentuan di atas, berdasarkan Pasal 1667 KUHPerdata mengatur bahwa:

\footnotetext{
${ }^{1}$ John Kenedi. (2016). Urgensi Penegakan Hukum dalam Hidup Berbangsa dan Bernegara. El-Afkar: Jurnal Pemikiran Keislaman dan Tafsir Hadis, Institut Agama Islam Negeri Bengkulu, 5(2), hlm. 51.

${ }^{2}$ Retnowulan Sutantio \& Iskandar Oeripkartawinata. (2003). Hukum Acara Perdata: Dalam Teori dan Praktek. Bandung: CV. Mandar Maju, hlm. 5.

${ }^{3}$ Y. Wartaya Winangun S. J. (2004). Tanah: Sumber Nilai Hidup. Yogyakarta: PT. Kanisius, hlm. 21.

${ }^{4}$ Nila Manda Sari \& Y. Yunanto. (2018). Cacat Hukum dalam Hibah sebagai Perjanjian Sepihak dan Implikasinya. Notarius, Universitas Diponegoro, 11(1), hlm. 101.

${ }^{5}$ Eman Suparman. (1995). Hukum Waris Indonesia: Dalam Perspektif Islam, Adat, dan BW. Bandung: CV. Mandar Maju, hlm. 73.

${ }^{6}$ Caturangga Situmeang \& Putri Tika Larasari. (2015). Analisis Hukum tentang Pembatalan Hibah (Studi Putusan Pengadilan Agama No: 887/PDT.G/2009/PA.MDN). Premise Law Jurnal, Universitas Sumatera Utara, 12, hlm. 2.

${ }^{7}$ Faizah Bafadhal. (2013). Analisis tentang Hibah dan Korelasinya dengan Kewarisan dan Pembatalan Hibah Menurut Peraturan Perundang-Undangan di Indonesia. Jurnal Ilmu Hukum, Universitas Jambi, 4(1), hlm. 18.

${ }^{8}$ Meylita Stansya Rosalina Oping. (2017). Pembatalan Hibah Menurut Pasal 1688 Kitab Undang-Undang Hukum Perdata. Lex Privatum, Universitas Sam Ratulangi, 5(7), hlm. 30.
} 
"Penghibahan hanya boleh dilakukan terhadap barang-barang yang sudah ada pada saat penghibahan itu terjadi. Jika hibah itu mencakup barang-barang yang belum ada, maka penghibahan batal sekedar mengenai barang-barang yang belum ada."

Pemberian hibah dilakukan dengan pembuatan akta hibah di hadapan pejabat umum yang berwenang. Khusus akta hibah untuk barang-barang yang bergerak, dibuat di hadapan Notaris, sedangkan untuk barang-barang yang tidak bergerak, pada umumnya dibuat di hadapan Pejabat Pembuat Akta Tanah (PPAT). ${ }^{9}$ Tugas pembuat akta tanah adalah melakukan sebagian kegiatan pendaftaran tanah dengan membuat akta sebagai hasil kegiatan tersebut beserta bukti dilakukannya perbuatan hukum untuk membantu atau melayani masyarakat yang memerlukan bukti tertulis otentik berkaitan dengan peristiwa atau perbuatan hukum tertentu. ${ }^{10}$

Adapun terkait pembatalan hibah, pada Pasal 1688 KUHPerdata mengatur bahwa suatu penghibahan tidak dapat dicabut dan karena itu tidak dapat pula dibatalkan, kecuali dalam hal-hal berikut:

(1) Jika syarat-syarat penghibahan itu tidak dipenuhi oleh penerima hibah;

(2) Jika orang yang diberi hibah bersalah dengan melakukan atau ikut melakukan suatu usaha pembunuhan atau suatu kejahatan lain atas diri penghibah;

(3) Jika penghibah jatuh miskin sedang yang diberi hibah menolak untuk memberi nafkah kepadanya.

Berdasarkan ketentuan pasal di atas, hibah dapat dibatalkan jika syarat-syarat pengecualiannya terpenuhi. Penarikan kembali hibah yang tersebut dilaksanakan dengan memberikan pernyataan atas kehendak pemberi kepada penerima hibah, disertai dengan penuntutan barang-barang yang telah dihibahkan, dimana masingmasing pihak mesti memperhatikan hak dan kewajiban satu sama lain. ${ }^{11}$ Akan tetapi, di dalam hubungan hukum tertentu, memungkinkan untuk timbul suatu keadaan dimana salah satu pihak tidak memenuhi kewajibannya terhadap pihak lain. Pada kondisi tersebut, pihak yang dirugikan dapat menuntut hak dan harus menuruti cara yang telah ditentukan dalam undang-undang. ${ }^{12}$

Pada hari Kamis tanggal 24 Oktober 2019, berdasarkan Putusan Pengadilan Negeri Pematangsiantar Nomor 33/Pdt.G/2019/PN.Pms tentang Perkara Perdata Pembatalan Akta Hibah Nomor 424/2014 terhadap Jumita Vani Timbul Sidabutar Selaku Tergugat (selanjutnya disebut Putusan PN Pematangsiantar No.33/Pdt.G/2019/PN.Pms). Dalam surat putusan yang dikeluarkan oleh pengadilan tersebut, pada bagian mengadili, khususnya pada sub-bagian dalam pokok perkara, mulai angka 1 (satu) hingga angka

\footnotetext{
${ }^{9}$ Duma Natalia D. Saragi. (2012). “Cacat Yuridis Pembuatan Akta Hibah oleh Pejabat Umum yang Berwenang: Tinjauan Yuridis Putusan Mahkamah Agung No. 850 K/PDT/2011”. Tesis. Magister Kenotariatan, Universitas Indonesia, Depok, hlm. 3.

${ }^{10}$ Habib Adjie. (2009). Hukum Notaris Indonesia: Tafsir Tematik terhadap UU No. 30 Tahun 2004 tentang Jabatan Notaris. Bandung: Refika Aditama, hlm. 73.

${ }^{11}$ Duma Natalia D. Saragi. (2012). Op. Cit., hlm. 3.

${ }^{12}$ Abdulkadir Muhammad. (2000). Hukum Acara Perdata Indonesia. Bandung: PT. Citra Aditya Bakti, hlm. 15.
} 
4 (empat) berturut-turut disebutkan bahwa:

1. Mengabulkan Gugatan Penggugat untuk sebahagian;

2. Menyatakan Akta Hibah No. 424/2014 Pada tanggal 14 Agustus 2014 yang diperbuat oleh Dharma Serpin Purba, SH selaku Pejabat Pembuat Akta Tanah Kota Pematang Siantar berdasarkan Sertifikat Hak Milik No. 1155 adalah Sah menurut hukum;

3. Menyatakan Tergugat melakukan perbuatan melawan hukum atas kesalahannya yang tidak adanya itikad baik untuk memberikan nafkah kepada Penggugat;

4. Menyatakan batal Akta Hibah Nomor 424/2014 tertanggal 14 Agustus 2014 yang dibuat oleh Notaris/PPAT Dharma Serpin Purba, SH;

Empat poin di atas merupakan sebagian dari isi putusan Majelis Hakim, dimana jika diperhatikan, terjadi pembatalan akta hibah (poin/angka 4) yang sebelumnya telah dinyatakan sah (poin/angka 2). Oleh karena itu, penulis tertarik dan memilih untuk meneliti Putusan PN Pematangsiantar No. 33/Pdt.G/2019/PN.Pms lebih jauh.

Berdasarkan uraian di atas maka tujuan penelitian ini adalah untuk mengetahui hak dan kewajiban pemberi hibah yang melakukan pembatalan hibah; akibat hukum terhadap penerima hibah yang kepadanya terjadi pembatalan hibah; serta untuk menganalisis kesesuaian Putusan PN Pematangsiantar No. 33/Pdt.G/2019/PN.Pms dengan ketentuan Peraturan Perundang-Undangan yang berlaku.

\section{METODE}

Jenis penelitian yang digunakan adalah penelitian hukum normatif, yaitu penelitian hukum yang dilakukan dengan cara meneliti bahan pustaka atau data sekunder. ${ }^{13}$ Penelitian hukum normatif dikenal pula sebagai penelitian dengan pendekatan doktrinal, dimana merupakan suatu proses untuk menelusuri bahan-bahan hukum yang relevan dengan objek yang dikaji. ${ }^{14}$ Penelitian ini bersifat deskriptif, yakni berupaya untuk mengambarkan dan memaparkan mengenai topik atau judul serta permasalahan yang muncul dari topik tersebut melalui studi kepustakaan yang terkait dengan pembatalan akta hibah di pengadilan Negeri Pematangsiantar. Bahan hukum yang digunakan dalam penelitian ini terdiri dari:

1. Bahan hukum primer, yaitu bahan-bahan hukum yang mengikat, antara lain:

a. Peraturan Kolonial, Staatsblad Nomor 23 Tahun 1847 tentang Burgerlijk Wetboek voor Indonesie (BW)/Kitab Undang-Undang Hukum Perdata;

b. Peraturan Kolonial, Staatsblad Nomor 52 Tahun 1847 tentang Reglement op de Burgerlijke Rechtsvordering (Rv)/Reglemen Hukum Acara Perdata;

c. Peraturan Pemerintah Republik Indonesia Nomor 24 Tahun 1997 tentang Pendaftaran Tanah;

\footnotetext{
${ }^{13}$ Soerjono Soekanto \& Sri Mamudji. (2013). Penelitian Hukum Normatif: Suatu Tinjauan Singkat. Jakarta: PT. Raja Grafindo Persada, hlm. 13.

${ }^{14}$ Sarah Sarmila Begem, Nurul Qamar, \& Hamza Baharuddin. (2019). Sistem Hukum Penyelesaian Pelanggaran Hak Asasi Manusia (HAM) Berat Melalui Mahkamah Pidana Internasional. SIGn Jurnal Hukum, CV. Social Politic Genius (SIGn), 1(1), hlm. 3.
} 
d. Peraturan Mahkamah Agung Republik Indonesia Nomor 1 Tahun 2016 tentang Prosedur Mediasi di Pengadilan; serta

e. Putusan Pengadilan Negeri Pematangsiantar Nomor 33/Pdt.G/2019/PN.Pms.

2. Bahan hukum sekunder, yaitu bahan yang memberikan penjelasan mengenai bahan hukum primer, seperti buku-buku literature, hasil-hasil penelitian, hasil karya dari kalangan hukum atau praktisi hukum yang berkaitan dengan akta hibah.

Untuk memperoleh data yang dibutuhkan dalam penelitian ini, maka digunakan teknik pengumpulan data, yakni sebagai berikut:

1. Dokumentasi, dilakukan dengan cara mengakses situs resmi pemerintah terkait lalu mengunduh bahan hukum yang terkait dalam penelitian;

2. Studi Kepustakaan, dilakukan dengan cara menginventarisasi dan menganalisis bahan-bahan hukum kepustakaan yang berkenaan dengan masalah yang dikaji dalam penelitian.

Adapun teknik analisis data yang digunakan adalah deskriptif kualitatif, dimana data yang telah dikumpulkan kemudian diolah dengan cara mengidentifikasi secara sistematis serta menghubungkan antar ketentuan yang terdapat dalam bahan hukum primer, sehingga menghasilkan pembahasan dalam bentuk kalimat yang tersusun secara sistematis, dan berujung pada penarikan suatu kesimpulan serta saran atau rekomendasi yang berkesesuaian dengan masalah yang dikaji dalam penelitian. ${ }^{15}$

\section{HASIL DAN PEMBAHASAN}

\section{A. Hak dan Kewajiban Pemberi Hibah yang Melakukan Pembatalan Hibah}

Hukum diartikan sebagai suatu perlindungan bagi kepentingan masyarakat yang berbentuk suatu norma beserta kaidah. Hubungan hukum yang terlihat pada konteks hibah adalah pemberi hibah selaku sebagai debitur dan penerima hibah selaku kreditur. ${ }^{16}$ Pembatalan suatu hibah dapat diartikan sebagai hubungan hukum yang sepihak antara pemberi hibah yang memberikan suatu hibah kepada penerima hibah yang memiliki kewajiban tanpa mendapatkan hak. Pemberi hibah dapat mengajukan suatu gugatan beserta pembatalan hibah apabila yang menerima hibah tidak memenuhi syarat sebagaimana yang telah diatur dalam KUHPerdata.

Hibah digolongkan pada perjanjian sepihak. KUHPerdata memberikan ketentuan terhadapnya, sehingga terdapat hak dan kewajiban pula di dalamnya. Hak dan kewajiban tersebut antara lain: ${ }^{17}$

\footnotetext{
${ }^{15}$ Nurul Qamar \& Farah Syah Rezah. (2020). Metode Penelitian Hukum: Doktrinal dan Non-Doktrinal. Makassar: CV. Social Politic Genius (SIGn), hlm. 10.

${ }^{16}$ Widya Anggraeni. (2006). "Tanggung Gugat Pemberi Hibah Akibat Pembatalan". Skripsi. Fakultas Hukum, Universitas Airlangga, Surabaya, hlm. 52.

${ }^{17}$ Amirudin Fardianzah. (2015). Pembatalan Akta Hibah yang Dibuat di Hadapan PPAT oleh Pemberi Hibah. Kumpulan Jurnal Mahasiswa Fakultas Hukum, Universitas Brawijaya, hlm. 5.
} 
1. Hak yang timbul dari peristiwa hibah:

a. Pemberi hibah berhak untuk memakai sejumlah uang dari harta atau benda yang dihibahkannya, asalkan hak ini telah diperjanjikan dalam penghibahan, sebagaimana berdasarkan Pasal 1669 dan Pasal 1671 KUHPerdata;

b. Pemberi hibah berhak untuk mengambil benda yang telah diberikannya jika si penerima hibah meninggal terlebih dahulu dari si penghibah, dengan catatan hal demikian hanya boleh diadakan untuk kepentingan penghibah sendiri, sebagaimana berdasarkan Pasal 1672 KUHPerdata;

c. Pemberi hibah dapat menarik kembali pemberiannya, jika penerima hibah tidak memenuhi kewajiban yang ditentukan dalam akta hibah atau hal-hal lain, sebagaimana berdasarkan Pasal 1688 KUHPerdata.

2. Kewajiban yang timbul dari peristiwa hibah:

a. Kewajiban pemberi hibah: setelah pemberi hibah menyerahkan harta atau benda yang dihibahkannya kepada si penerima hibah, maka semenjak itu pula tidak ada lagi kewajiban-kewajiban yang mengikat pemberi hibah;

b. Kewajiban penerima hibah: KUHPerdata memberikan kemungkinan bagi penerima hibah untuk melakukan suatu kewajiban kepada penerima hibah, yakni antara lain: pertama, penerima hibah berkewajiban untuk melunasi hutang-hutang penghibah atau benda-benda lain, dengan catatan hutang dan beban yang harus dibayar telah disebutkan secara tegas dalam akta hibah. Kedua, penerima hibah diwajibkan untuk memberikan tunjangan nafkah kepada pemberi hibah apabila pemberi hibah jatuh miskin. Ketiga, penerima hibah diwajibkan untuk mengembalikan benda yang telah dihibahkan berdasarkan aturan-aturan yang telah diatur dalam KUHPerdata.

Pemberi hibah dapat menyerahkan seluruh hak miliknya kepada pihak lain, tanpa imbalan apapun dari si penerima hibah tersebut. Maka Undang-Undang membuat aturan yang mewajibkan si penerima hibah untuk memasukkan kembali semua harta yang sudah diterima. ${ }^{18}$ Berkaitan dengan itu, dalam penarikan kembali hibah, salah satu pihak harus mempertahankan haknya dan pihak lain dibebani untuk melakukan suatu kewajiban. Lebih jauh lagi pihak-pihak yang dirugikan dapat menuntut haknya bilamana: ${ }^{19}$

"Setiap orang harus memenuhi atau mentaati peraturan hukum yang telah ditetapkan. Tetapi di dalam suatu hubungan hukum yang telah terjadi, kemungkinan timbul suatu keadaan yang mana pihak yang satu tidak memenuhi kewajibannya terhadap pihak yang lainnya. Sehingga pihakyang satunya merasa dirugikan. Pihak yang merasa dirugikan dapat menuntut haknya tetapi harus menurut cara yang telah ditentukan di dalam undang-undang."

${ }^{18}$ Anisitus Amanat. (2001). Membagi Warisan berdasarkan Pasal-Pasal Hukum Perdata BW. Jakarta: PT. Raja Grafindo Persada, hlm. 70.

${ }^{19}$ Apri Rotin Djusfi \& Jumadi Winata. (2018). Penyelesaian Sengketa Hibah Menurut Kitab Undang-Undang Hukum Perdata. Ius Civile: Refleksi Penegakan Hukum dan Keadilan, Universitas Teuku Umar, 2(2), hlm. 115. 
Upaya hukum yang dapat dilakukan untuk menuntut hak adalah dengan mengajukan gugatan ke pengadilan, yaitu meminta kepada hakim untuk memeriksa dan memutus perkara yang disengketakan. Mengenai proses penyelesaian pembatalan akta hibah melalui pengadilan ini tidaklah mudah dilakukan karena dalam proses persidangan itu memerlukan adanya suatu pembuktian. Penentuan beban pembuktian merupakan masalah yang tidak mudah karena tidak ada satu pasal pun yang mengatur secara tegas tentang pembagian beban pembuktian. ${ }^{20}$

Proses pembatalan hibah pada dasarnya dapat dilakukan dengan pengajuan gugatan dengan materi pokok pembatalan hibah. Sebagaimana lazimnya, pengajuan gugatan terjadi apabila terdapat suatu sengketa antara para pihak. Sehubungan dengan hal tersebut, penyusunan suatu gugatan mesti memperhatikan beberapa aspek, yaitu: ${ }^{21}$

a. Tiap orang yang merasa dirugikan dapat mengajukan gugatan terhadap pihak yang dianggap merugikan lewat pengadilan.

b. Gugatan dapat diajukan secara lisan atau tertulis dan bila perlu dapat minta bantuan Ketua Pengadilan Negeri.

c. Gugatan itu harus diajukan oleh yang berkepentingan.

d. Tuntutan hak di dalam gugatan harus merupakan tuntutan hak yang ada kepentingan hukumnya, yang dapat dikabulkan apabila kebenarannya dapat dibuktikan dalam sidang pemeriksaan.

e. Mengenai persyaratan tentang isi daripada gugatan tidak ada ketentuannya, namun berdasarkan Pasal 8 ayat (3) Peraturan Kolonial, Staatsblad Nomor 52 Tahun 1847 tentang Reglement op de Burgerlijke Rechtsvordering (Rv)/ Reglemen Hukum Acara Perdata, mengharuskan adanya pokok gugatan yang meliputi: Identitas para pihak, dalil-dalil konkret tentang adanya hubungan hukum yang merupakan dasar serta alasan-alasan daripada tuntutan (dalildalil tersebut lebih dikenal dengan istilah fundamentum petendi), serta tuntutan atau petitum tersebut harus jelas dan tegas.

\section{B. Akibat Hukum terhadap Seorang Penerima Hibah yang Kepadanya Terjadi Pembatalan Hibah}

Akibat hukum adalah akibat-akibat yang timbul karena adanya suatu perbuatan atau peristiwa hukum, sesuai dengan aturan-aturan yang berlaku. ${ }^{22}$ Akibat hukum tersebut dapat melahirkan suatu kewajiban dan hak bagi para pihak yang melakukan suatu tindakan hukum. Akibat hukum bisa terjadi karena pembatalan hibah yang akan menimbulkan akibat hukumnya pada harta hibah. ${ }^{23}$

\footnotetext{
${ }^{20}$ Ibid.

${ }^{21}$ R. Soeroso. (2003). Praktik Hukum Acara Perdata: Tata Cara dan Proses Persidangan. Bandung: Sinar Grafika, hlm. 26.

${ }^{22}$ Sudarsono. (2007). Kamus Hukum. Jakarta: PT. Rineka Cipta, hlm. 24.

${ }^{23}$ Sovia Hasanah. (2019, 28 May). Arti Perbuatan Hukum, Bukan Perbuatan Hukum dan Akibat Hukum. Dalam HukumOnline.com. Diakses pada tanggal 3 Agustus 2020.
} 
Pada dasarnya, akibat dari pembatalan merupakan ketika berlakunya surut dan ketika kembali pada dalam keadaan semula atau ex tunc. Batalnya hibah diakibatkan karena ketidakcakapan, sebagaimana berdasarkan Pasal 1688 KUHPerdata, yang berakibat pengembalian objek hibah dalam keadaan semula sebelum dibuat perjanjian, sebagaimana berdasarkan Pasal 1691 KUHPerdata. ${ }^{24}$

Akibat dari batalnya hibah merupakan batal demi hukum karena adanya suatu tuntutan yang memiliki akibat yang sama yaitu tidak mempunyai akibat hukum atau yang diutamakan. Dalam yurisprudensi, terdapat dua kategori untuk dikatakan batal demi hukum, yaitu: ${ }^{25}$

1. kebatalan absolut adalah suatu perbuatan hukum yang batal demi hukum, karena atas perbuatan hukum sejak terjadinya suatu perbuatan hukum tidak memiliki akibat hukum;

2. kebatalan relatif adalah perbuatan hukum yang dapat dibatalkan, dimana keadaannya disahkan dalam perbuatan hukum yang digantungkan pada kemauan salah satu pihak.

Segala macam benda yang telah dihibahkan harus dikembalikan jika terjadinya pembatalan hibah dalam keadaan bersih dan beban yang melekat. Akibat hukum dapat timbul kepada penerima hibah jika dimohonkan batalnya pada pengadilan untuk memperoleh putusan yang berketetapan hukum tetap, dimana seluruh harta hibah yang telah diberikan terhadap setiap penerima hibah akan kembali menjadi milik sendiri pemberi hibah secara keseluruhan. Sedangkan Akibat hukum terhadap pihak ketiga jika terjadi pembatalan objek hibah adalah yang sudah diberikannya terhadap penerima hibah terlebih dahulu harus dikembalikan kepada ahli waris yang mutlak. ${ }^{26}$

Jika dihubungkan dengan isi Putusan PN Pematangsiantar No. 33/Pdt.G/2019/ PN.Pms, pemberi hibah dituntut untuk mengembalikan harta atau objek yang dihibahkan. Lebih lanjut, berdasarkan salinan surat Putusan PN Pematangsiantar No. 33/Pdt.G/2019/PN.Pms, hubungan para pihak dalam kaitan dengan harta atau objek yang dihibahkan, belum melibatkan pihak ketiga, karena pihak penggugat adalah juga sekaligus merupakan pemberi hibah. Sehingga dengan terpenuhinya bukti-bukti bahwa penerima hibah tidak memenuhi syarat pemberian hibah, maka pemberi hibah dapat mengajukan permohonan pembatalan akta hibah tersebut pada pengadilan sehingga pembatalan akta hibah memiliki kekuatan hukum tetap. Selanjutnya, ketika pengadilan telah memberikan putusan dengan kekuatan hukum tepat tentang pengembalian harta hibah, maka pihak penerima hibah, demi hukum dan keadilan harus mengembalikan harta hibah tersebut.

\footnotetext{
${ }^{24}$ R. Soeroso. (2003). Loc. Cit.

${ }^{25}$ Amirudin Fardianzah. (2015). Op. Cit., hlm. 18.

${ }^{26}$ Retnowulan Sutantio \& Iskandar Oeripkartawinata. (2003). Op. Cit., hlm. 76.
} 


\section{Putusan PN Pematangsiantar No. 33/Pdt.G/2019/PN.Pms}

Dalam upaya untukmenganalisis kesesuaian putusan pengadilanyang menjadi subjek penelitian ini dengan ketentuan perundang-undangan yang berlaku, pemahaman atas duduk perkara Putusan PN Pematangsiantar No. 33/Pdt.G/2019/PN.Pms merupakan satu hal yang urgen. Pada uraian di bawah ini, dijelaskan secara berturutturut mengenai duduk perkara yang mendasari Putusan PN Pematangsiantar No. 33/Pdt.G/2019/PN.Pms, serta analisis terhadapnya lebih lanjut.

\section{Duduk Perkara}

Pihak penggugat dalam Putusan PN Pematangsiantar No. 33/Pdt.G/2019/ PN.Pms merupakan pemilik sah sebidang tanah yang luasnya $184 \mathrm{~m}^{2}$ berdasarkan sertifikat hak milik Nomor 1155. Tanah milik penggugat tersebut telah dihibahkan kepada tergugat yang merupakan anak angkat dari penggugat. Beberapa tahun belakangan, hubungan penggugat yang menghibahkan tanah dengan tergugat yang menerima hibah tersebut mengalami kondisi yang kurang harmonis secara hubungan keluarga. Beriringan dengan hal tersebut, umur penggugat yang semakin tua telah mengakibatkannya tidak bisa bekerja dan kemudian mengalami keterpurukan ekonomi. Penggugat selaku pemberi hibah kemudian jatuh miskin.

Penggugat telah meminta kepedulian kepada tergugat untuk membantu kebutuhan, serta merawatnya. Akan tetapi, tergugat menolak atau tidak memberikan bantuan (tidak menafkahi penggugat). Tindakan tergugat yang menolak untuk menafkahi penggugat tersebut merupakan tindakan yang tidak menunjukkan atau memberikan itikad baik untuk merawat diri pemberi hibah yang jatuh miskin, dimana hal demikian merupakan suatu perbuatan yang melawan hukum.

Lebih lanjut, harta yang dihibahkan kepada tergugat selaku anak angkat dari penggugat ialah sebidang tanah yang di atasnya berdiri bangunan permanen berbentuk rumah dengan luas tanah $184 \mathrm{~m}^{2}$ (seratus delapan puluh empat meter persegi) berdasarkan sertifikat hak milik nomor 1155 yang dikeluarkan oleh Badan Pertanahan Kota Pematangsiantar, yang tercatat atas nama pemegang hak Nursinta Manik, dan terletak di Lorong 29, Kel. Siopat Suhu, Kec. Siantar Timur, Kota Pematangsiantar.

Salah satu syarat bolehnya dilakukan pembatalan hibah adalah ketika si penerima hibah tidak mempunyai itikad baik untuk menafkahi pemberi hibah yang jatuh miskin, sebagaimana berdasarkan Pasal 1688 ayat (3) KUHPerdata yang mengatur bahwa:

"Suatu penghibahan tidak dapat dicabut dan karena itu tidak dapat pula dibatalkan, kecuali dalam hal... jika penghibah jatuh miskin sedang yang diberi hibah menolak untuk memberi nafkah kepadanya." 
Dari ketentuan di atas dan kaitan dengan Putusan PN Pematangsiantar No. 33/ Pdt.G/2019/PN.Pms, disebutkan bahwasanya penggugat tidak mau menafkahi atau menolak memberi bantuan atas kebutuhan penggugat. sementara usia si pemberi hibah semakin bertambah dan tidak dapat mencari nafkah untuk memenuhi semua kebutuhan sehingga mengalami keterpurukan perekonomian atau jatuh miskin.

Majelis hakim dalam Putusan PN Pematangsiantar No. 33/Pdt.G/2019/ PN.Pms, telah melakukan upaya perdamaian di antara kedua belah pihak melalui mediasi, sebagaimana diatur dalam Peraturan Mahkamah Agung Republik Indonesia Nomor 1 Tahun 2016 tentang Prosedur Mediasi di Pengadilan. Akan tetapi, upaya perdamaian tersebut tidak berhasil. Bahwa eksepsi diartikan sebagai suatu sanggahan atau bantahan dari kedua belah pihak yang tidak mengenai suatu pokok perkara. ${ }^{27}$ Bahwa di dalam eksepsi tergugat dikemukakan kecuali, dimana keluar dari kewenangan hakim, tidak boleh diajukan dan dipertimbangkan secara sendiri, sehingga tetap dipertimbangkan dan diperiksa bersama-sama dengan pokok gugatan.

Majelis hakim kemudian berpendapat bahwa tergugat merupakan anak yang tidak berbakti kepada orangtua, yakni tidak melaksanakan kewajiban sebagai anak untuk merawat dan mengasihi pemberi hibah selaku orang tua angkat penerima hibah. Sementara pemberi hibah telah merawat penerima dari kecil hingga berumah tangga. Lebih lanjut, tergugat tidak memberikan bantuan baik secara moril dan materil kepada penggugat selaku pemberi hibah. Majelis hakim kemudian memutuskan Putusan PN Pematangsiantar No. 33/ Pdt.G/2019/PN.Pms, bahwa:

a. Mengabulkan Gugatan Penggugat untuk sebahagian;

b. Menyatakan Akta Hibah No. 424/2014 Pada tanggal 14 Agustus 2014 yang diperbuat oleh Dharma Serpin Purba, SH selaku Pejabat Pembuat Akta Tanah Kota Pematang Siantar berdasarkan Sertifikat Hak Milik No. 1155 adalah Sah menurut hukum;

c. Menyatakan Tergugat melakukan perbuatan melawan hukum atas kesalahannya yang tidak adanya itikad baik untuk memberikan nafkah kepada Penggugat;

d. Menyatakan batal Akta Hibah Nomor 424/2014 tertanggal 14 Agustus 2014 yang dibuat oleh Notaris/PPAT Dharma Serpin Purba, SH;

e. Menyatakan sebidang tanah yang di atasnya berdiri bangunan Permanen berbentuk rumah dengan luas tanah 184 M2 (Seratus Delapan Puluh Empat Meter persegi) berdasarkan Sertifikat Hak Milik Nomor 1155 yang dikeluarkan oleh Badan Pertanahan Kota Pematangsiantar tanggal 28 Mei 2007, tercatat atas nama pemegang hak Nursinta Manik, yang terletak di

${ }^{27}$ Sudikno Mertokusumo. (1998). Hukum Acara Perdata Indonesia. Yogyakarta: Liberty, hlm. 116. 
Lorong 29, Kel. Siopat Suhu, Kec. Siantar Timur, Kota Pematangsiantar dengan batas-batas sebagai berikut:

- Sebelah Timur Berbatasan dengan: Tanah Negara;

- Sebelah Barat Berbatasan dengan: Tanah Negara;

- Sebelah Selatan Berbatasan dengan: Jalan/Lorong 29;

- Sebelah Utara Berbatasan dengan: Tanah Negara.

Adalah sah secara hukum milik Penggugat;

f. Memerintahkan kepada Tergugat untuk menyerahkan tanah terperkara berikut bangunan permanen berbentuk rumah di atasnya kembali kepada Penggugat seluas 184 M2 (Seratus Delapan Puluh Empat Meter persegi) berdasarkan Sertifikat Hak Milik Nomor 1155, dengan batas-batas sebagai berikut:

- Sebelah Timur Berbatasan dengan: Tanah Negara;

- Sebelah Barat Berbatasan dengan: Tanah Negara;

- Sebelah Selatan Berbatasan dengan: Jalan/Lorong 29;

- Sebelah Utara Berbatasan dengan: Tanah Negara;

g. Menghukum Tergugat untuk membayar uang paksa (Dwangson) sebesar Rp. 100.000,-(seratus ribu rupiah) per hari apabila lalai dalam melaksanakan putusan ini setelah mempunyai kekuatan hukum yang tetap;

h. Menghukum Tergugat untuk membayar biaya perkara hingga saat ini ditetapkan sejumlah Rp. 1.026.000.-(satu juta dua puluh enam ribu rupiah);

i. Menghukum Tergugat untuk mematuhi putusan ini;

j. Menolak Gugatan Penggugat untuk selain dan selebihnya.

\section{Analisis Putusan}

Analisis putusan perkara dalam pembatalan hibah sebaiknya dilihat dalam pemutusan sengketa pembatalan hibah majelis hakim, dengan memperhatikan hak-hak para pihak atas hibah yang disengketakan serta mengedepankan bukti. Dalam pertimbangan hukum, majelis hakim harus menggunakan hukum positif yang berlaku di Indonesia sehingga diterapkan putusan yang seadil-adilnya.

Berdasarkan Putusan PN Pematangsiantar No. 33/Pdt.G/2019/PN.Pms, majelis hakim menggunakan beberapa pertimbangan, yang antara lain adalah bahwa sesuai dengan bukti Penggugat dan Tergugat bertanda P-1 dan T-3 yaitu Sertifikat Hak Sertifikat Nomor 1155/Siopat Suhu hibah dan P-3 dan T-2 Akta Hibah Nomor 424/2014 tertanggal 14 Agustus 2014 yang dibuat oleh Notaris/ PPAT Dharma Serpin Purba, SH, maka harus pula berdasarkan Pasal 37 ayat (1) Peraturan Pemerintah Republik Indonesia Nomor 24 Tahun 1997 tentang Pendaftaran Tanah yang mengatur bahwa:

"Peralihan hak atas tanah dan hak milik atas satuan rumah susun melalui jual beli, tukar menukar, hibah, pemasukan dalam perusahaan dan perbuatan hukum pemindahan hak lainnya, kecuali pemindahan 
hak melalui lelang hanya dapat didaftarkan jika dibuktikan dengan akta yang dibuat oleh PPAT yang berwenang menurut ketentuan peraturan perundang-undangan yang berlaku."

Kemudian, majelis hakim juga mengambil pertimbangan bahwa berdasarkan uraian pertimbangan di atas, Penggugat yang mempunyai tanah dan bangunan berdasarkan Sertifikat Hak Milik Nomor 1155/SiopatSuhu sebagai pemegang hak milik pertama dan telah menghibahkannya kepada Tergugat berdasarkan Akta Hibah Nomor 424/2014 tertanggal 14 Agustus 2014 dibuat dihadapan Notaris/ PPAT Dharma Serpin Purba, SH dan Tergugat telah pula membalik namakan Sertifikat Hak Milik Nomor 1155/Siopat Suhu menjadi atas nama Tergugat ke Badan Pertanahan Nasional Pematangsiantar, dimana Penggugat juga tidak memiliki keturunan atau ahli waris lainnya sesuai dengan bukti P-2 yaitu Kartu Keluarga atas nama Kepala Keluarga adalah Penggugat, maka pemberian Hibah yang dilakukan Penggugat terhadap Tergugat adalah sah menurut hukum.

Selain pertimbangan di atas, majelis hakim juga menimbang bahwa pada prinsipnya pemberian Hibah dari pemberi hibah kepada si penerima hibah tidak dapat ditarik kembali sebagaimana berdasarkan Pasal 1666 KUHPerdata, namun terdapat aturan pengecualian sebagaimana berdasarkan Pasal 1688 KUHPerdata.

Setelah berbagai pertimbangan digunakan oleh majelis hakim, serta memastikan keseluruhan bukti, barulah kemudian memberikan muatan putusan sebagaimana yang telah dijelaskan dalam pembahasan sebelumnya. Oleh karena itu, berdasarkan berbagai pertimbangan majelis hakim, serta dengan memperhatikan Peraturan Perundang-Undangan yang berlaku, khususnya yang termuat dalam KUHPerdata, dapat disimpulkan bahwa Putusan PN Pematangsiantar No. 33/Pdt.G/2019/PN.Pms, telah sesuai dengan ketentuan perundang-undangan yang berlaku.

\section{KESIMPULAN DAN SARAN}

Berdasarkan uraian hasil dan pembahasan, maka dapat disimpulkan bahwa Pemberi hibah memiliki beberapa hak sebagaimana berdasarkan Pasal 1669, Pasal 1671, dan Pasal 1672 KUHPerdata. Pemberi hibah juga dapat menarik kembali pemberiannya, jika penerima hibah tidak memenuhi kewajiban yang ditentukan dalam akta hibah atau hal-hal lain, sebagaimana berdasarkan Pasal 1688 KUHPerdata. Selanjutnya, akibat hukum terhadap penerima hibah yang kepadanya terjadi pembatalan hibah ialah pengembalian objek hibah dalam keadaan semula sebelum dibuat perjanjian, sebagaimana berdasarkan Pasal 1691 KUHPerdata, dan disertai putusan yang berketetapan hukum tetap. Adapun mengenai Putusan PN Pematangsiantar No. 33/ Pdt.G/2019/PN.Pms, dapat disimpulkan bahwa keputusan tersebut telah sesuai dengan peraturan perundang-undangan yang berlaku. Dengan dasar kesimpulan tersebut, diharapkan kepada pemberi hibah agar sebelum memberikan suatu hibah 
perlu dipertimbangkan dengan matang, sehingga objek atau harta yang dihibahkan dapat diterima oleh orang yang tepat, serta untuk menghindari kemungkinankemungkinan yang tidak diinginkan. Lebih lanjut, disarankan kepada penerima hibah untuk mematuhi segala hal yang tertuang dalam akta hibah dan juga Pasal 1688 KUHPerdata, sehingga dapat meminimalisir pembatalan atas Akta Hibah. Adapun Majelis hakim dalam menangani suatu perkara perdata, dapat melakukan upaya mediasi secara optimal, sebagaimana berdasarkan Peraturan Mahkamah Agung Republik Indonesia Nomor 1 Tahun 2016 tentang Prosedur Mediasi di Pengadilan.

\section{REFERENSI}

Abdulkadir Muhammad. (2000). Hukum Acara Perdata Indonesia. Bandung: PT. Citra Aditya Bakti.

Amirudin Fardianzah. (2015). Pembatalan Akta Hibah yang Dibuat di Hadapan PPAT oleh Pemberi Hibah. Kumpulan Jurnal Mahasiswa Fakultas Hukum, Universitas Brawijaya, hlm. 1-22.

Anisitus Amanat. (2001). Membagi Warisan berdasarkan Pasal-Pasal Hukum Perdata $B W$. Jakarta: PT. Raja Grafindo Persada.

Apri Rotin Djusfi \& Jumadi Winata. (2018). Penyelesaian Sengketa Hibah Menurut Kitab Undang-Undang Hukum Perdata. Ius Civile: Refleksi Penegakan Hukum dan Keadilan, Universitas Teuku Umar, 2(2), hlm. 109-121.

Caturangga Situmeang \& Putri Tika Larasari. (2015). Analisis Hukum tentang Pembatalan Hibah (Studi Putusan Pengadilan Agama No: 887/PDT.G/2009/ PA.MDN). Premise Law Jurnal, Universitas Sumatera Utara, 12, hlm. 1-18.

Duma Natalia D. Saragi. (2012). "Cacat Yuridis Pembuatan Akta Hibah oleh Pejabat Umum yang Berwenang: Tinjauan Yuridis Putusan Mahkamah Agung No. 850 K/ PDT/2011". Tesis. Magister Kenotariatan, Universitas Indonesia, Depok.

Eman Suparman. (1995). Hukum Waris Indonesia: Dalam Perspektif Islam, Adat, dan $B W$. Bandung: CV. Mandar Maju.

Faizah Bafadhal. (2013). Analisis tentang Hibah dan Korelasinya dengan Kewarisan dan Pembatalan Hibah Menurut Peraturan Perundang-Undangan di Indonesia. Jurnal Ilmu Hukum, Universitas Jambi, 4(1), hlm. 16-32.

Habib Adjie. (2009). Hukum Notaris Indonesia: Tafsir Tematik terhadap UU No. 30 Tahun 2004 tentang Jabatan Notaris. Bandung: Refika Aditama.

John Kenedi. (2016). Urgensi Penegakan Hukum dalam Hidup Berbangsa dan Bernegara. El-Afkar: Jurnal Pemikiran Keislaman dan Tafsir Hadis, Institut Agama Islam Negeri Bengkulu, 5(2), hlm. 51-62.

Meylita Stansya Rosalina Oping. (2017). Pembatalan Hibah Menurut Pasal 1688 Kitab Undang-Undang Hukum Perdata. Lex Privatum, Universitas Sam Ratulangi, 5(7), hlm. 29-35.

Nila Manda Sari \& Y. Yunanto. (2018). Cacat Hukum dalam Hibah sebagai Perjanjian Sepihak dan Implikasinya. Notarius, Universitas Diponegoro, 11(1), hlm. 100-114. 
Nurul Qamar \& Farah Syah Rezah. (2020). Metode Penelitian Hukum: Doktrinal dan Non-Doktrinal. Makassar: CV. Social Politic Genius (SIGn).

Peraturan Kolonial, Staatsblad Nomor 23 Tahun 1847 tentang Burgerlijk Wetboek voor Indonesie (BW)/Kitab Undang-Undang Hukum Perdata.

Peraturan Kolonial, Staatsblad Nomor 52 Tahun 1847 tentang Reglement op de Burgerlijke Rechtsvordering (Rv)/Reglemen Hukum Acara Perdata.

Peraturan Mahkamah Agung Republik Indonesia Nomor 1 Tahun 2016 tentang Prosedur Mediasi di Pengadilan. (Berita Negara Republik Indonesia Tahun 2016 Nomor 175).

Peraturan Pemerintah Republik Indonesia Nomor 24 Tahun 1997 tentang Pendaftaran Tanah. (Lembaran Negara Republik Indonesia Tahun 1997 Nomor 59. Tambahan Lembaran Negara Republik Indonesia Nomor 3696).

Putusan Pengadilan Negeri Pematangsiantar Nomor 33/Pdt.G/2019/PN.Pms tentang Perkara Perdata Pembatalan Akta Hibah Nomor 424/2014 terhadap Jumita Vani Timbul Sidabutar Selaku Tergugat.

R. Soeroso. (2003). Praktik Hukum Acara Perdata: Tata Cara dan Proses Persidangan. Bandung: Sinar Grafika.

Retnowulan Sutantio \& Iskandar Oeripkartawinata. (2003). Hukum Acara Perdata: Dalam Teori dan Praktek. Bandung: CV. Mandar Maju.

Sarah Sarmila Begem, Nurul Qamar, \& Hamza Baharuddin. (2019). Sistem Hukum Penyelesaian Pelanggaran Hak Asasi Manusia (HAM) Berat Melalui Mahkamah Pidana Internasional. SIGn Jurnal Hukum, CV. Social Politic Genius (SIGn), 1(1), hlm. 1-17. doi: https://doi.org/10.37276/sjh.v1i1.28

Soerjono Soekanto \& Sri Mamudji. (2013). Penelitian Hukum Normatif: Suatu Tinjauan Singkat. Jakarta: PT. Raja Grafindo Persada.

Sovia Hasanah. (2019, 28 May). Arti Perbuatan Hukum, Bukan Perbuatan Hukum dan Akibat Hukum. Dalam HukumOnline.com. Diakses dari https://www.hukumonline. com/klinik/detail/ulasan/lt5ceb4f8ac3137/arti-perbuatan-hukum--bukanperbuatan-hukum-dan-akibat-hukum, pada tanggal 3 Agustus 2020.

Sudarsono. (2007). Kamus Hukum. Jakarta: PT. Rineka Cipta.

Sudikno Mertokusumo. (1998). Hukum Acara Perdata Indonesia. Yogyakarta: Liberty.

Widya Anggraeni. (2006). "Tanggung Gugat Pemberi Hibah Akibat Pembatalan". Skripsi. Fakultas Hukum, Universitas Airlangga, Surabaya.

Y. Wartaya Winangun S. J. (2004). Tanah: Sumber Nilai Hidup. Yogyakarta: PT. Kanisius.

Alyatama Budify, Jelitamon Ayu Lestari Manurung, \& Satria Braja Harianja. (2020). ' Pembatalan Akta Hibah di Pengadilan Negeri Pematangsiantar: Kajian Putusan ! I Nomor 33/Pdt.G/2019/PN.Pms. SIGn Jurnal Hukum, CV. Social Politic Genius (SIGn), ' I 2(1), hlm. 72-85. doi: https://doi.org/10.37276/sjh.v2i1.77

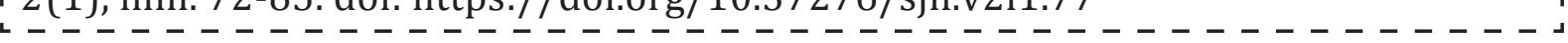

